\title{
SINKHOLES AND A DISAPPEARING LAKE: VICTORY LAKE CASE STUDY
}

\author{
Dr. TAMie J. Jovanelly \\ Associate Professor of Geology, Berry College, P.O. Box 495036, Mount Berry, GA 30149, tjovanelly@berry.edu
}

\begin{abstract}
Human-induced sinkhole collapse can result in drastic changes to landscape aesthetics and present challenges to land managers seeking to determine the plausibility of restoration, the amount of financial investment needed, and the long-term sustainability of tampering with karstic environments. Alteration of groundwater flow in a karstic environment expedited the formation of large sinkholes in the southern end of man-made Victory Lake, causing it to drain immediately. Soon after the lake emptied in 1986, two unsuccessful attempts were made to restore the 13 ha (32 ac) lake. The sinkholes formed in the southern basin were completely in-filled, eliminating 3 ha (8 ac) of lake basin and significantly altering the original lake morphology. Some twenty-seven years later, Victory Lake is holding some water in the shallow basin at the northern end and would primarily be classified as a marshy wetland. This study was initiated to investigate the current relationship between the groundwater and surface water at the lake's altered basin to determine the potential for it to be restored fully or partially as a recreational focal point of the Berry College campus. Over the course of one year we measured the inputs (stream flow and precipitation) and outputs (evaporation and surface water outflow) of the lake system. We were able to conclude that groundwater is not likely contributing to the lake, based on inorganic and stable isotope $\left({ }^{18} \mathrm{O}\right.$ and $\left.{ }^{2} \mathrm{H}\right)$ water chemistry analysis and the deep position of the groundwater table relative to the lake bottom. From the results of dye-tracer tests conducted in the lake, we concluded that basin water may not be escaping downward at measurable rates because of its clay bottom. Our overall water-budget analysis confirms an adequate water volume entering by rainfall and ephemeral stream inflow; nearly $90 \%$ of the water leaves Victory Lake through surface-water outflow. Water loss through evapotranspiration during spring and summer months overcomes the gain accomplished during wetter and cooler months, particularly February. Through an investigation of water level records kept for campus monitoring wells from 1998 through 2012 we confirm that the groundwater table has stabilized and the immediate threat of new sinkhole formation is minimal. Restoration of Victory Lake to its original picturesque meeting spot may be possible through creative engineering strategies and project financing. However, we question the longevity of managing a karstic environment and consider the potential risks to infrastructure, groundwater, and human health should lake bottom failure occur again on campus.
\end{abstract}

\section{INTRODUCTION}

During the late 1980s geologists began to report an increasing pace of human-induced sinkholes in the eastern United States, with particular focus on the changing landscapes in Georgia, Alabama, and Florida (MacIntyre, 1986; Newton, 1987). More recently, stress on and overuse of the Florida aquifer has led to several occurrences of emptied lakes, including Lake Jackson (1619 ha; 4,000 ac) and Lake Scott (115 ha; 285 ac) (Penson, 2002; McBride et al., 2011). Human-induced sinkholes often result from dewatering by wells, quarries, and mines in limestone environments (Newton, 1987; Fidelibus et al., 2011). The processes forming sinkholes can be enhanced by humaninduced change in the groundwater hydrologic regime by either inflows or outflows resulting from pumping activities (Benito et al., 1995; Martinez et al., 1998; Florea et al.,
2009). Surface subsidence can develop within a matter of days when highly soluble rocks dissolve due to anthropogenic pressures (Martinez et al., 1998). The location of sinkhole collapse and speed of formation, rather than the diameter or depth, dictate the threat to human life and the potential for economic loss (Newton, 1987). To date, the Federal Emergency Management Agency reports that insurance claims relating to sinkholes, either natural or human-induced, in the United States totals \$100 million annually. Sinkhole formation is closely related to local hydrologic conditions, and human-induced changes to the local hydrology commonly accelerate the process. It has been shown that areas in the eastern United States that have a higher sinkhole density tend to show a lower water quality due to the direct pathway of contamination from surface to the groundwater table (Lindsey et al., 2010). An understanding of groundwater and surface water interac- 
tions in karstic environments is essential for aquifer protection and the development of local water resources (Praise and Gunn, 2007; McBride et al., 2011).

Previous studies have indicated the usefulness of creating water budgets for lakes in karstic terrains (Dalton et al., 2004; McBride et al., 2011; Aurit et al., 2013). More specifically, the great seasonal variability of lakes' water budgets tied to the Florida aquifer and the repercussions to surrounding communities has been the focus of recent United States Geological Survey investigations (Dalton et al., 2004; Spechler, 2010; McBride et al., 2011; Sepúlveda et al., 2012). The research conducted at Lake Seminole (Dalton et al., 2004) provided the framework for the water budget completed in this study. Dalton lists the challenges to measuring evaporation or evapotranspiration over a hydrologic year and emphasizes the importance of it as a driver in seasonal lake volume. Human impact on groundwater resources may have been best highlighted by Spechler (2010) in his study of the Florida aquifer in southcentral Florida. Spechler was able to illustrate the stresses of population growth on the groundwater level. In addition, Spechler's results show the high variability over time in aquifer water quality from a large sampling of 129 area wells. The study by McBride et al. reports a four-year water budget of Lake Panasoffkee in west-central Florida and focuses on the groundwater and surface water connectedness of a karstic system. In their study, environmental isotopes of strontium, oxygen, and hydrogen confirm interplay between groundwater and surface-water systems. In addition, they were able to discern through the stable isotope analysis that rainfall was a primary source of groundwater recharge within the Lake Panasoffkee watershed. The recent USGS publication by Sepúlveda et al. uses measured water budget parameters of runoff, infiltration, lake water levels, stream flows, and evapotranspiration measured from 1995-2006 in east-central Florida to compute the interaction of groundwater flow system with the surface environment using MODFLOW-2005. This model allowed them to make some predictions about longterm groundwater recharge and withdrawal rates.

A water budget systematically quantifies the gain, loss, and storage of water in the water cycle using the principle of the conservation of mass. Typical field measurements for a water budget include precipitation, groundwater inflow, surface water inflow, evaporation, transpiration, groundwater outflow, and surface water outflow. For water-supply planning and management, water budgets for aquifers and watersheds are an important tool used to determine fluctuations and stress on the system (Winstanley et al., 2006; Healy et al., 2007). As all components of the water cycle are connected, estimating future water budgets allows planners and managers to evaluate water availability and the impacts of withdrawals on the system. Data collected for water budgets are often used for understanding current hydrological conditions so that future outcomes can be forecast.
A water budget can be used to explore the impact on a single parameter or the entire system to a variable such as temperature. Many researchers opt for defining a water budget based on the response of one inflow or outflow parameter (Loague and Freeze, 1985; Winter, 1985; Deevey, 1988; Hebbert and Smith, 1990). The isolation of a single parameter, such as groundwater, may make it easier to identify the response of associated streams, lakes, or wetlands (Winter, 1999). For example, Winstanley and Wendland (2007) used a water budget to investigate response to climate change over time, and they showed the influence of temperature on water availability.

Water budgets are not limited by geographical scale. Some range from a small drainage basin, as in this study $\left(11 \mathrm{~km}^{2}\right)$, to considerably larger areas like the $618 \mathrm{~km}^{2}$ explored by Shuster et al. (2003). However, as was the focus of a paper by Hamilton-Smith (2006) and reiterated by Horvat and Rubinic (2006), the start of a quality water budget begins with the accurate delineation of the total catchment area.

Despite variations in project size, scope, and region of study, two questions persist in water budget analysis: What is the best way to measure evaporation, and what is the error in such estimates? Winter (1981) found that annual averages had smaller errors ( 2 to $15 \%$ ) than monthly averages ( 2 to $30 \%)$. It appears that the preference in how evaporation is measured depends on the amount of data available or the amount of time and money a study has to commit. Using Class A pan evaporation measurements and Georgia Automated Environmental Monitoring Network (GAMEN) data as controls, Dalton et al. (2004) evaluated six different methods of calculating lake evaporation rates. The complexity and the amount of data needed, such as windspeed, humidity, and solar radiation for these methods varies greatly. Dalton et al. (2004) and Rosenberry et al. (1993) determined that the energy-budget method was 8 to $26 \%$ more reliable than empirically derived equations and ultimately provided the best match if raw data are unavailable.

\section{Site Description}

Victory Lake $\left(34^{\circ} 17^{\prime} 54^{\prime \prime} \mathrm{N}, 85^{\circ} 12^{\prime} 07^{\prime \prime} \mathrm{W}\right)$ is a recreational man-made lake that was completed in 1928 (Fig. 1). This picturesque spot on the Berry College campus provided a place for the college community to walk, picnic, and canoe. It has been important to Berry College and its alumni for decades. In 1953, Berry College sold mineral rights to a limestone quarry operator approximately $0.8 \mathrm{~km}$ west of Victory Lake. The quarry had successful mining operations for the next thirty-three years (Fig. 2a). By June 1986, the open-pit quarry was $110-\mathrm{m}$ deep and daily pumping rates topped 52,616 $\mathrm{m}^{3} \mathrm{~s}^{-1}$ (Richard Fountain, personal communication). At this time, the recorded depth to the water table on the Berry College campus was $44 \mathrm{~m}$. Overnight, four large sinkholes more than $6 \mathrm{~m}$ in diameter 




Figure 1. Location map of Victory Lake near Mount Berry, Georgia, showing its proximity to the quarry, surface-water sampling locations, monitoring wells, and other data sources. Geologic units and fault position estimated from Crawford (1990) [from Tom Crawford's unpublished 1990 geologic map of the Berry College campus.].

formed in the southern basin of Victory Lake that caused the lake to empty (Fig. 2b). Presumably, a cone of depression formed from the intense pumping at the quarry that caused the bottom of that part of the lake, which was over limestone, to collapse. The sinkholes were completely filled with earth materials after a few failed attempts at lake restoration (Fig. 2c). The lake basin was now reduced by 3 ha $(8 \mathrm{ac})$, and water that originally drained through a tributary now left by way of a culvert. Some twenty-seven years later, siltation, plant encroachment, and beaver dams have turned Victory Lake into a shallow basin full of vegetation. Currently, the basin is only known to hold water for a short duration following a hard rainfall (Fig. 2d).

The purpose of this study is to determine the possibility of restoration of a lake influenced by karst topography. To do this, we conducted a fourteen-month investigation to measure the inflow and outflow components of the present-day Victory Lake's water budget. The goals of the water budget were to identify how lake volume responds to current patterns in seasonal changes in precipitation and temperature, to determine if groundwater is substantially adding to or leaving the system, to determine if current basin morphology is influencing the amount of water that the basin holds, and, ultimately, to determine the potential of lake restoration.

\section{Study Area And Geologic Setting}

Karstic features resulting from limestone dissolution are commonplace in the northwest Georgia physiographic region called the Ridge and Valley (Hubbard, 1988). The nearly two hundred caves mapped in the Cumberland Plateau north of Mount Berry are unlike Ridge and Valley underground caverns because they are typically connected and do not remain solitary underground voids (Jenkins, 2009; Buhlmann, 2001). Most of the voids in the Ridge and Valley region are formed by solution processes along fractures, joints, and bedding planes (Weary, 2005).

Two types of sinkholes occur most commonly in the Ridge and Valley region: cover-collapse and cover-subsidence (Hubbard, 1988). Cover-collapse sinkholes form when the surficial sediments contain a large amount of clay. The clay binds the soil so that it can bridge small cavities, but not large ones. Cover-subsidence sinkholes form when surficial sediments filter into cavities to gradually form surface depressions. (Florea et al., 2009). Although cover-subsidence sinkholes are known to be more destructive, both sinkhole varieties can pose risk to human health and economic risk to urban planners, developers, homeowners, and insurance companies (Scheidt et al., 2005). These types of natural sinkhole development are generally not predictable, although sinkholes can be expected where limestone formations are found (Newton, 1987).

The geology exposed at the surface around the perimeter of Victory Lake varies. The bedrock found under the western side of Victory Lake is predominately Mississippian-age limestone. This limestone is part of the Conasauga Formation. The Conasauga Formation consists of siltstone, claystone, shale, and limestone and was described by Anderson (1993). The formation is easily identifiable within the numerous sinkholes found in the forested area lining the western side of the lake. The contact between the shale and the limestone units of the Conasauga Formation can be seen at the quarry, however, the lower contact of the Conasauga Formation on Berry College's main campus is not exposed. From our review of the well logs from the twenty-two monitoring wells on campus that were drilled in 1998, the boundary is not clear. The maximum depth drilled in these monitoring wells is $93 \mathrm{~m}$ below the surface. The eastern side of the lake has exposures of Cambrian age sandstone. This sandstone is part of the Rome Formation, which consists of sandstone, siltstone, and claystone. This formation is known for tightly folded and steeply tilted beds (Anderson, 1993).

The geologic map of the Rome, Georgia, area was completed by Tom Crawford in 1990, but not published. Some revisions and additions were made by $\mathrm{C}$. Williams in 1993. Crawford and Williams identified a normal fault, referred to as the Rome Fault, that crosscuts the southern portion of Victory Lake. To the east of this fault, and to the south of the quarry, Crawford and Williams also identified several vertical joint sets exposed in outcrops.

\section{Hydrological Setting}

Victory Lake is located in a topographically low area compared to regions immediately adjacent to it. The rim of the quarry's elevation is 189 masl, whereas Victory Lake's

Journal of Cave and Karst Studies, December 2014 •219 




Figure 2. Aerial photography of Victory Lake. The $\mathrm{X}$ in photos $\mathrm{A}, \mathrm{B}, \mathrm{C}$ indicates the southeastern-most tip of Victory Lake. The photograph shown in D was taken from the southeastern-most position (X) looking north. A. This aerial photograph shows early stages of quarry excavation in 1964 and a full Victory Lake. B. This aerial photograph (1987) shows an empty Victory Lake. Notice that vegetation has not yet entered the basin. C. This 2012 aerial photograph (Google Earth) illustrates current conditions at Victory Lake. D. A photograph of Victory Lake after March (2008) rains. 


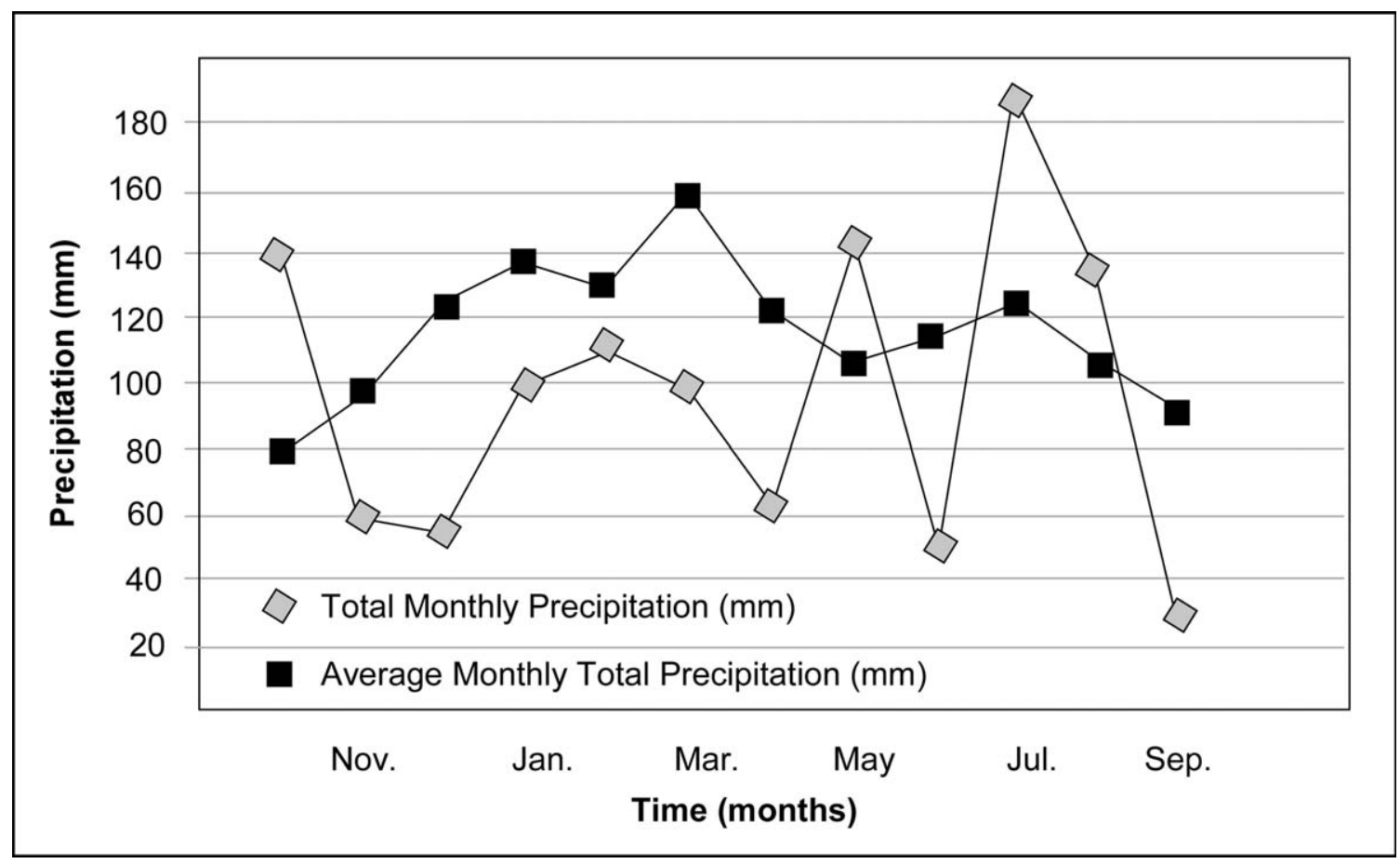

Figure 3. Average monthly total (1910-2009) precipitation ( $\mathrm{mm}$ ) measured for Rome, Georgia, (black squares) compared to the total monthly precipitation $(\mathrm{mm})$ measured at Victory Lake for October 2007 to September 2008 (grey diamond). Average monthly total data were retrieved from the Georgia Automated Environmental Monitoring Network website www. georgiaweather.net.

elevation is approximately 181 masl. Under normal conditions, the groundwater flow pattern in the area is from west to east and follows the regional topography of the landscape.

An ephemeral stream with drainage basin approximately $5.0 \mathrm{~km}^{2}$ enters Victory Lake on its northern end. Pre-1986, this creek continued from the southern end of Victory Lake to merge with Big Dry Creek. Today, a culvert funnels water from Victory Lake into Big Dry Creek.

Twenty-two monitoring wells (PZ26A and PZ16A) were installed on the main campus in June 1998 following the collapse of several campus buildings into sinkholes. The locations of two wells used for groundwater sampling in this study are shown on Figure 1. The water level data recorded from 1998-2000 provides valuable insight as to the significant depletion of the aquifer during and after the time of pumping; the quarry officially closed in 2000 . The lowest depth-to-water measurement $(47 \mathrm{~m})$ was recorded in the well at the southern end of Victory Lake in July 1998. The water table immediately rebounded after quarry operations were halted. The current average depth to the water table is $10 \mathrm{~m}$.

\section{Climate}

The mean temperature for Mount Berry over a thirtyyear period is $16.5{ }^{\circ} \mathrm{C}$. August is typically the warmest month, averaging $32.2{ }^{\circ} \mathrm{C}$; January the coldest, averaging
$11.8{ }^{\circ} \mathrm{C}$. Average annual rainfall is $1425 \mathrm{~mm}$; generally, the highest monthly rainfall occurs during March and the lowest in October. The hydrologic and climatic data collected for this paper represents one hydrologic year starting October 1 and ending September 30; see Figures 3 and 4.

\section{Materials And Methods}

\section{Establishing Lake Water Budget}

The water budget equation used in this study is $(P+I)$ $-(E T+O)=\Delta S$, where $P$ is precipitation, $I$ is inflow, $E T$ is evapotranspiration, $O$ is outflow, and $\Delta S$ is change in storage. All water budget measurements are converted to $\mathrm{m}^{3}$. Annual and seasonal water balances were computed based on a method from McCarthy et al. (1991) and Chescheir et al. (1995). The expression for percentage closure error is $\left(\Delta S_{\text {calc }}-\Delta S_{\text {meas }}\right) / \mathrm{F} \times 100 \%$, where $F$ is the system flux $\left(\mathrm{m}^{3}\right)$ expressed as $F=(P+I+O+E T+$ $\left.\left|\Delta S_{\text {calc }}\right|\right) / 2$ and $\Delta S_{\text {calc }}$ is the residual storage and $\Delta S_{\text {meas }}$ is the measured storage.

Inflow and outflow stream velocity were measured weekly using a Price AA flow meter. The inflow velocity was measured at the confluence of a tributary and Victory Lake, and the outflow was measured at the culvert where the lake water has been diverted to prevent road flooding. Stage gauges were placed in these locations to measure changes in water depth over time.

Journal of Cave and Karst Studies, December 2014 •221 


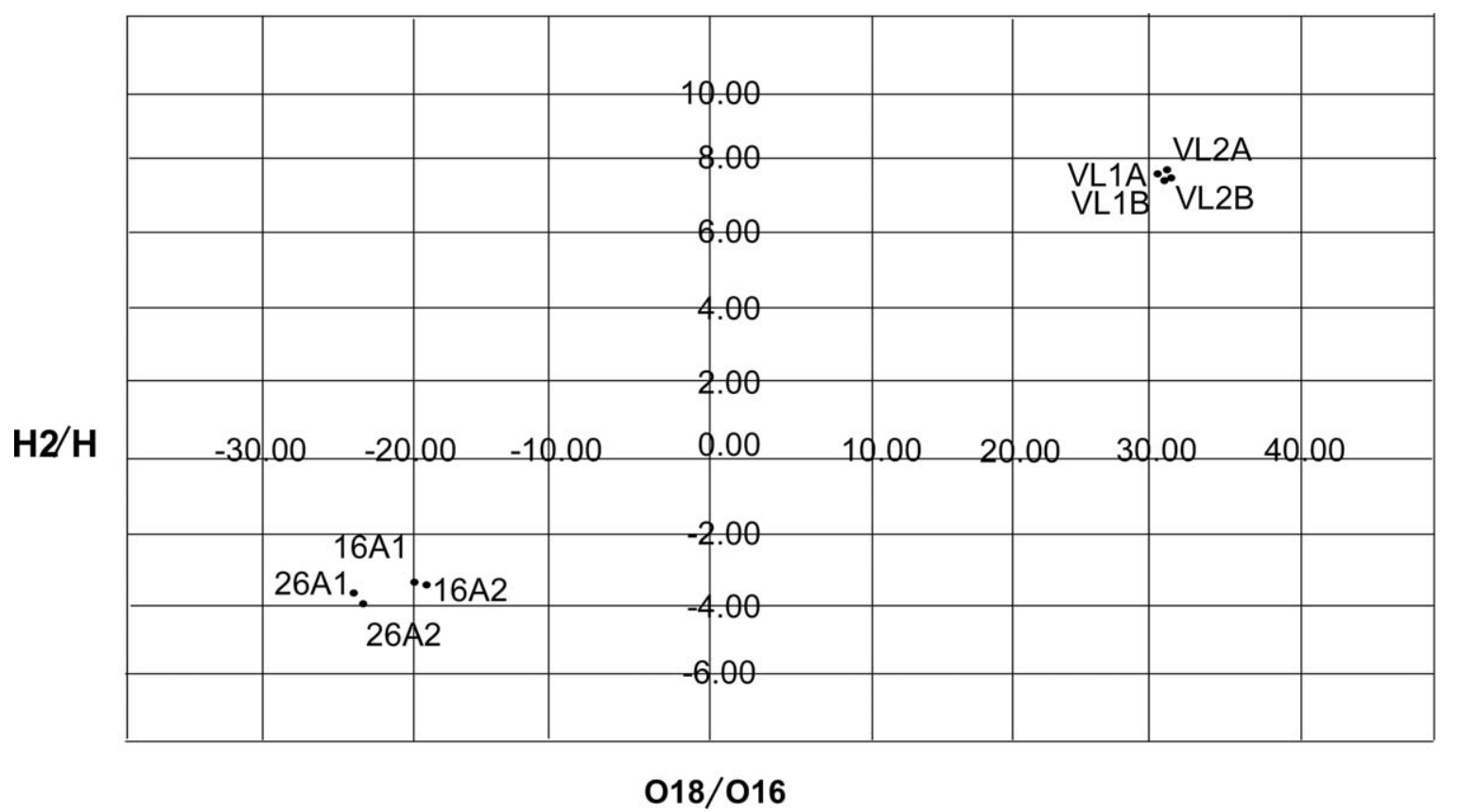

Figure 4. Average minimum/maximum monthly temperature $\left({ }^{\circ} \mathrm{C}\right)$ measured for Rome, GA. Average data was retrieved from the Georgia Automated Environmental Monitoring Network website www.georgiaweather.net.

To measure precipitation onto Victory Lake, postmounted butyrate-plastic rain gauges made to U.S. Weather Service specifications were placed in an open area at the northern and southern ends of the basin. These data were collected daily.

A Class AA evaporation pan was placed adjacent to Victory Lake in an open field free from shade and wind obstruction. The evaporation pan was visited daily from October 2007 to September 2008. The evaporation pan was stored for the winter months of December to February. Data for evapotranspiration came from the Georgia Environmental Monitoring Network website for the city of Rome.

Inorganic water chemistry data was analyzed from both the groundwater and surface water. Groundwater samples were collected at two monitoring wells in close proximity to Victory Lake (Fig. 1). Each well was purged for three hours before sample collection. Samples were immediately analyzed for general water chemistry at Berry College. Those samples collected for environmental isotopes $\left({ }^{18} \mathrm{O}\right.$ and ${ }^{2} \mathrm{H}$ ) were immediately placed on dry ice and mailed overnight to the University of Waterloo in Canada for analysis. The stable isotope composition of water is reported with reference to the Standard Mean Ocean Water, in parts per thousand (Craig, 1961).

A Rhodamine WT (C.I. Acid Red 388) dye tracer test was conducted in March 2008 to establish groundwater outflow or lack thereof. Standards and a calibration curve were created using concentrated stock solution of Rhodamine WT for the Model 10 Turner Designs Fluorometer. The measured injection of Rhodamine WT was based on the total liters of water calculated to be in Victory Lake during March 2008. Six liters of dye $(1.428 \mathrm{~kg})$ was introduced by slug injection at the northern entrance of Big Dry Creek. Groundwater samples were retrieved at monitoring well PZ26A (Fig. 1) hourly for 24 consecutive hours, then once every 4 hours for two days, then every day for three weeks.

\section{RESUlTS}

\section{GROUNDWATER}

Table 1 compares inorganic water chemistry for the groundwater and surface water samples. The groundwater has higher alkalinity (222 to $246 \mathrm{mg} \mathrm{L}^{-1}$ ) when compared to the surface water samples (110 to $\left.132 \mathrm{mg} \mathrm{L}^{-1}\right)$. In addition, the $\mathrm{CO}_{2}$ is considerably higher in the groundwater (18-20 mg L $\left.{ }^{-1}\right)$ than in the surface water samples ( 0 to $\left.5 \mathrm{mg} \mathrm{L}^{-1}\right)$. There is little variation in the amount of dissolved oxygen and nitrates among the samples. The warmer surface water has a lower $\mathrm{pH}$ than that of the groundwater.

Groundwater and surface water samples were analyzed for ${ }^{18} \mathrm{O}$ and ${ }^{2} \mathrm{H}$ (Fig. 5). All of the surface water samples contain larger fractions of ${ }^{18} \mathrm{O}$ and ${ }^{2} \mathrm{H}$ than the groundwater samples. The groundwater samples have a lighter signature for both ${ }^{2} \mathrm{H}$ (ranging from -3.18 to $-3.94 \%$ ) and ${ }^{18} \mathrm{O}$ (ranging from -18.54 to $-22.48 \%$ ).

The wells monitored (PZ26A and PZ16A) during the rhodamine-WT dye-tracer test are both located at the southern end of the lake (Fig. 1). Our fluorometer analysis did not detect any amounts of Rhodamine WT dye in the 
Table 1. Surface water and groundwater chemical analyses.

\begin{tabular}{|c|c|c|c|c|c|}
\hline \multirow[b]{2}{*}{ Test } & \multicolumn{3}{|c|}{ Surface Water Samples } & \multicolumn{2}{|c|}{ Groundwater Samples } \\
\hline & $1-\mathrm{VL}$ & 2-VL & $3-\mathrm{VL}$ & PZ26A & PZ16A \\
\hline Alkalinity, $\mathrm{mg} \mathrm{L}^{-1}$ & 132 & 112 & 110 & 246 & 222 \\
\hline $\mathrm{CO}_{2}, \mathrm{mg} \mathrm{L}^{-1}$ & 0 & 5 & 0 & 20 & 18 \\
\hline Nitrate-Nitrogen, $\mathrm{mg} \mathrm{L}^{-1}$ & $<4.4$ & 0 & $<0.2$ & $<2$ & $<1$ \\
\hline Phosphate, $\mathrm{mg} \mathrm{L}^{-1}$ & 0 & 0 & 0 & 2 & 1 \\
\hline Temperature, ${ }^{\circ} \mathrm{C}$ & 27 & 26.5 & 27 & 17 & 16.8 \\
\hline $\mathrm{pH}$ & 7 & 6.9 & 6.8 & 7.7 & 7.7 \\
\hline
\end{tabular}

groundwater samples collected throughout the three-week sampling duration.

\section{Precipitation}

The sampling months of October 2007 through September 2008 were classified as moderate drought to near-normal conditions (National Oceanic and Atmospheric Administration website, www.cpc.ncep.noaa.gov). From January 2008 to September 2008 the total rainfall recorded at Victory Lake was $915.37 \mathrm{~mm}$. This was $175.54 \mathrm{~mm}$ lower than the yearly average for Rome, Georgia (Fig. 3). The average mean monthly temperatures recorded during the duration of the study correlates within 2 degrees to the long-term monthly average temperatures for all months, except October 2007 and December 2007, which were warmer than historic average (Fig. 4).

\section{EVAPORATION}

Because of the extensive in-filling of the remaining basin with sediment over twenty-seven years and the resulting overgrowth of plants, we deem evapotranspiration at Victory Lake to be more influential than evaporation. For this reason, the data we present is the evapotranspiration reported for the city of Rome found from the Georgia Environmental Monitoring Network.

\section{INFLOW AND OUTFLOW}

Because Big Dry Creek is ephemeral, it only flows during periods of heavy and intense rainfall. Figure 6 compares stream inflow to direct rainfall onto the surface of the lake from October 2007 to November 2008. During periods of high rainfall, such as the months of December 2007 through March 2008, stream inflow is the dominant

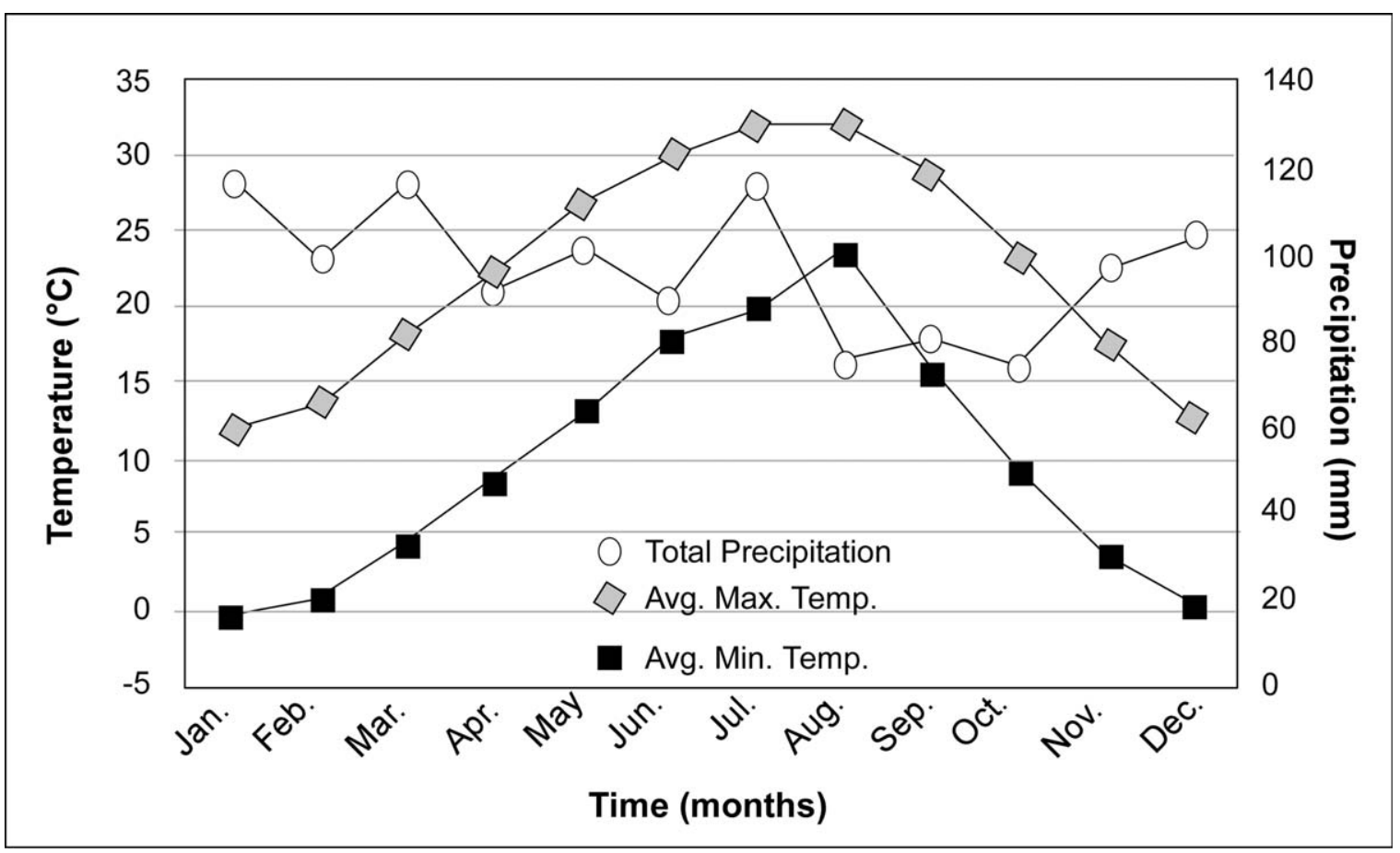

Figure 5. Groundwater (samples $16 \mathrm{~A}$ and 26A) and surface water (samples VL1 and VL2) analyses for stable isotopes $\delta{ }^{18} \mathrm{O}$ and $\delta{ }^{2} \mathrm{H}$. 


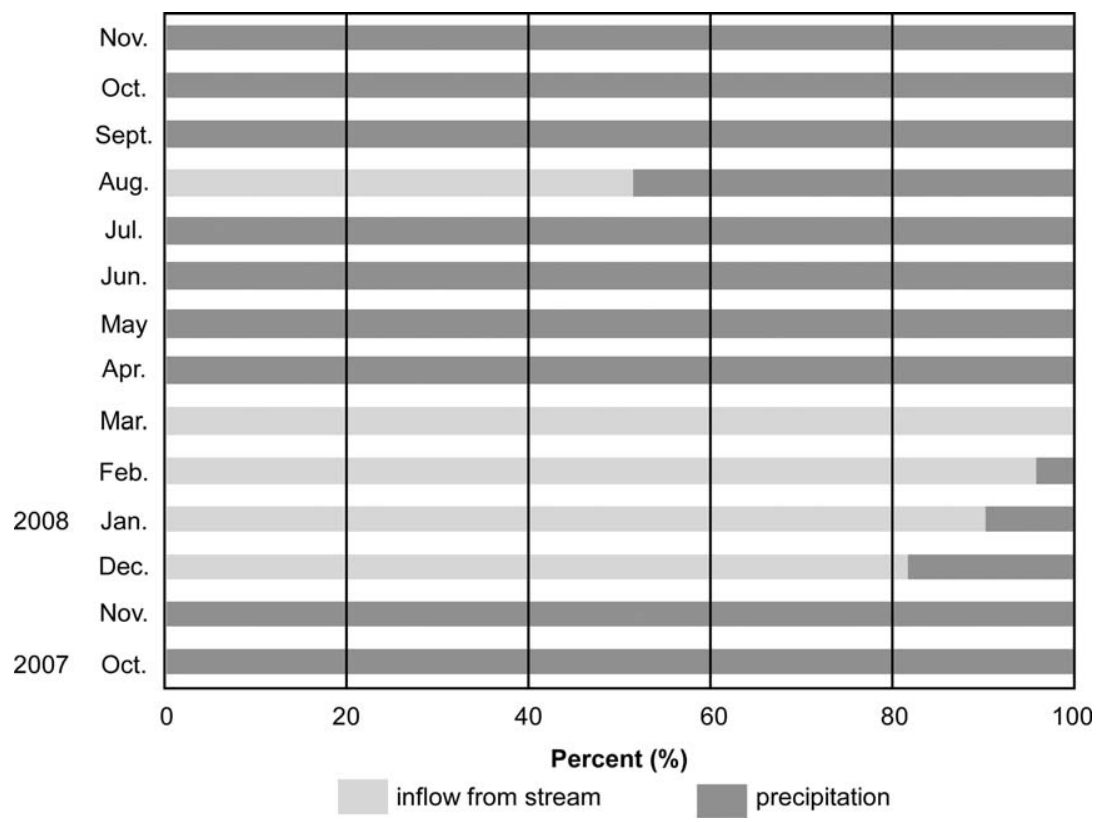

Figure 6. The percentages contributed to the water gain in Victory Lake by inflow from Big Dry Creek and rainfall directly onto the surface from October 2007 to November 2008.

process adding to the water volume in the basin. Rainfall onto its surface will be the major contributor to Victory Lake during the rest of the year. Similarly to inflow, water flow, in this case to downstream Big Dry Creek, is the dominant process of water loss when there are periods of high and intense precipitation (Fig. 7).

\section{WATER BALANCE}

Over the one-year study, Victory Lake's overall water budget indicates that the basin lost more water via evapotranspiration and surface water outflow $(50.3 \%)$ than it gained via rainfall and stream inflow (49.7\%) (Fig. 8). Which is the dominant variable, stream inflow,

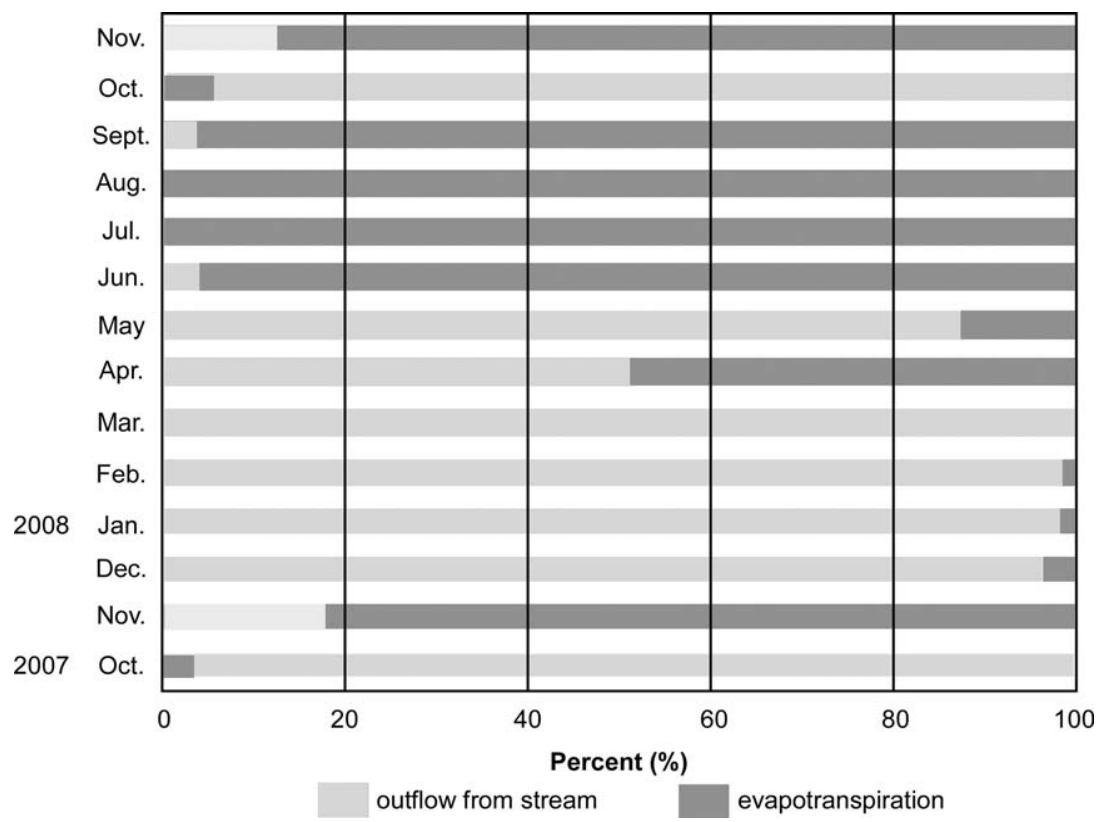

Figure 7. The percentages contributed to the water loss from Victory Lake by flow through the exit culvert and evapotranspiration from October 2007 to November 2008. 


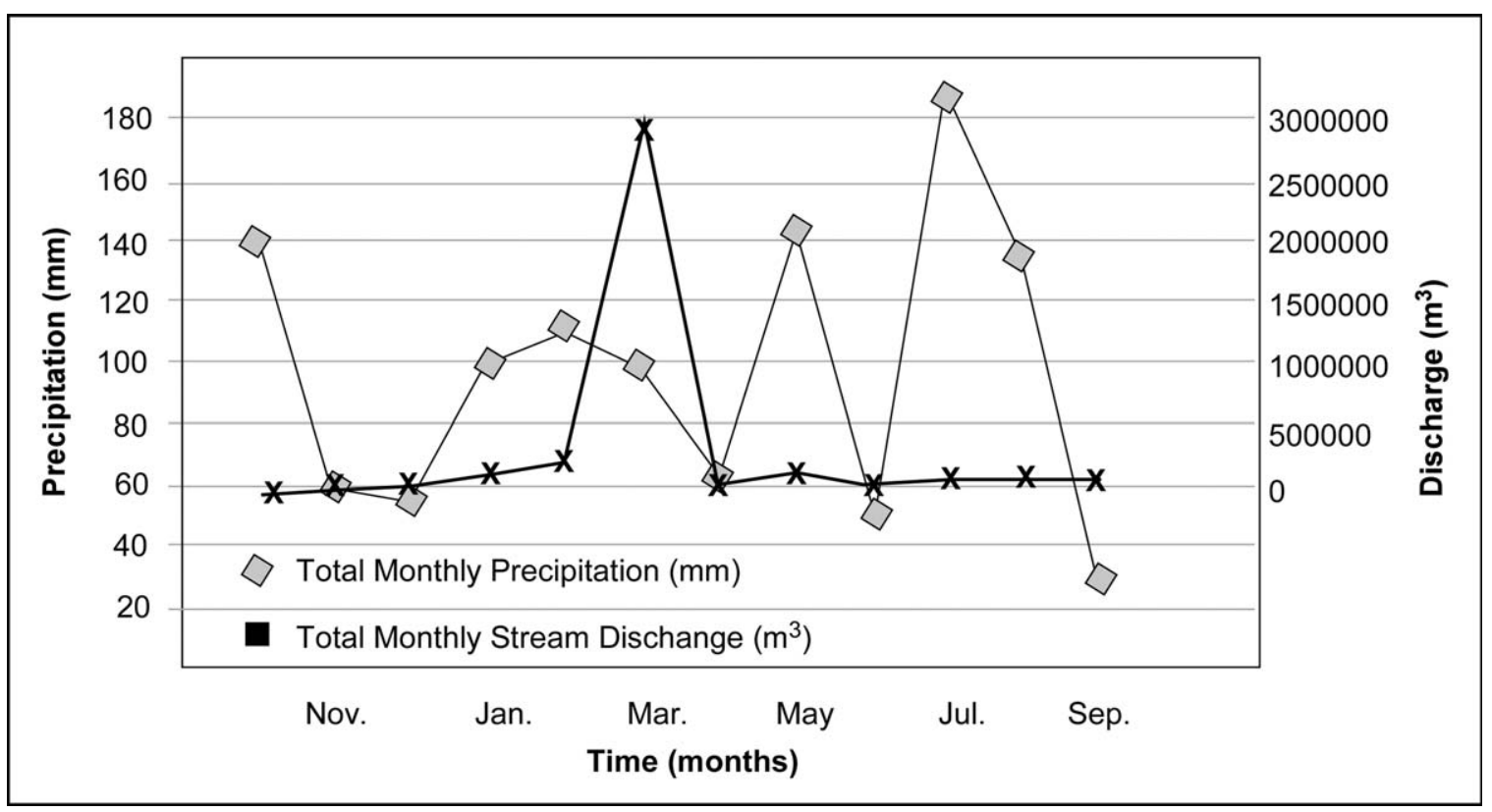

Figure 8. Total monthly precipitation recorded during the study $(\mathrm{mm})$ compared to total monthly Victory Lake outflow through the exit culvert $\left(\mathrm{m}^{3}\right)$.

rainfall, evapotransiration, or stream outflow, varies seasonally. During the summer and fall months, the lake's outflow was driven by evapotranspiration, $67 \%$ and $54 \%$, respectively. During the winter, water left the basin by stream outflow $(48 \%)$. Water left the basin during the spring via outflow $(41 \%)$ and evapotranspiration $(37 \%)$.

Gains or losses in storage were determined by comparing the monthly fluctuations to the initial volume and surface area measured for the lake at the start of the study; the overall change for the year being negative (Table 2). Monthly increases in storage ranging from 5\% to $23 \%$ occurred from October 2007 to January 2008 (Table 2). From October 2007 to January 2008 the lake volume doubles. By February 2008, however, there is a $62 \%$ decrease in storage. This reduction is followed by increases in rainfall additions and surface water inflow from spring rain events. By March 2008, the lake volume increased to 10 times that of the initial lake volume determined in September 2007. The March rains provided enough precipitation to completely fill in the lake basin. After the March storms, the storage in Victory Lake began to decrease despite May precipitation doubling that recorded in April. Losses continued to be calculated generally from May to November 2008, with a slight positive rebound in September.

A comparison of monthly inflow types (Fig. 6) reveals that direct rainfall dominated the gain during most of the study; in nine of fourteen months rainfall onto the lake contributed $100 \%$ to the inflow water budget (Fig. 6). During the winter and early spring, however, the stream provided more than $80 \%$ of the monthly inflow water budget (Fig. 6). Likewise, outflow through the culvert is the dominant process more than $90 \%$ of the time (Fig. 7). Evapotranspiration is prominent at the start of spring (March) and again in June and July, with over 95\% of water being lost through plant growth then (Table 2).

\section{DisCUSSION}

The results from the chemical analyses indicate that the groundwater shows much higher evidence of alkalinity (222 and $246 \mathrm{mg} \mathrm{L}^{-1}$ compared to 110 to $132 \mathrm{mg} \mathrm{L}^{-1}$ ) (Table 1). This is a typical characteristic of water pumped from a limestone aquifer (McBride et al., 2011). In addition, $\mathrm{CO}_{2}$ is also considerably higher in the groundwater, 18 and $22 \mathrm{mg} \mathrm{L}^{-1}$ compared to the surface water's 0 to $5 \mathrm{mg} \mathrm{L}^{-1}$. This pattern likely emerges because $\mathrm{CO}_{2}$ is more soluble in cold water, and the monitoring well is a closed system. The variation in the amount of dissolved oxygen and nitrates between surface and groundwater is slight. As anticipated, the surface water is warmer and has a lower $\mathrm{pH}$ than that of the groundwater.

The Craig and Gordon (1965) model established that environmental isotopes ${ }^{18} \mathrm{O}$ and ${ }^{2} \mathrm{H}$ respond to changes in temperature, therefore analyzing ${ }^{18} \mathrm{O}$ and ${ }^{2} \mathrm{H}$ is particularly useful in the study of groundwater and surface water interactions. Several authors have successfully applied isotopic fractionation of ${ }^{18} \mathrm{O}$ and ${ }^{2} \mathrm{H}$ as a means to distinguish between groundwater and surface water in water budgets (Krabbenhoft et al., 1990a, 1990b, 1994; Yehdeghoa et al., 1997). More recently, McBride et al. (2011) used stable isotopes for similar purposes to establish inflow and outflow in a water budget. Thus, if the groundwater and surface water are connected, the ${ }^{18} \mathrm{O}$ 


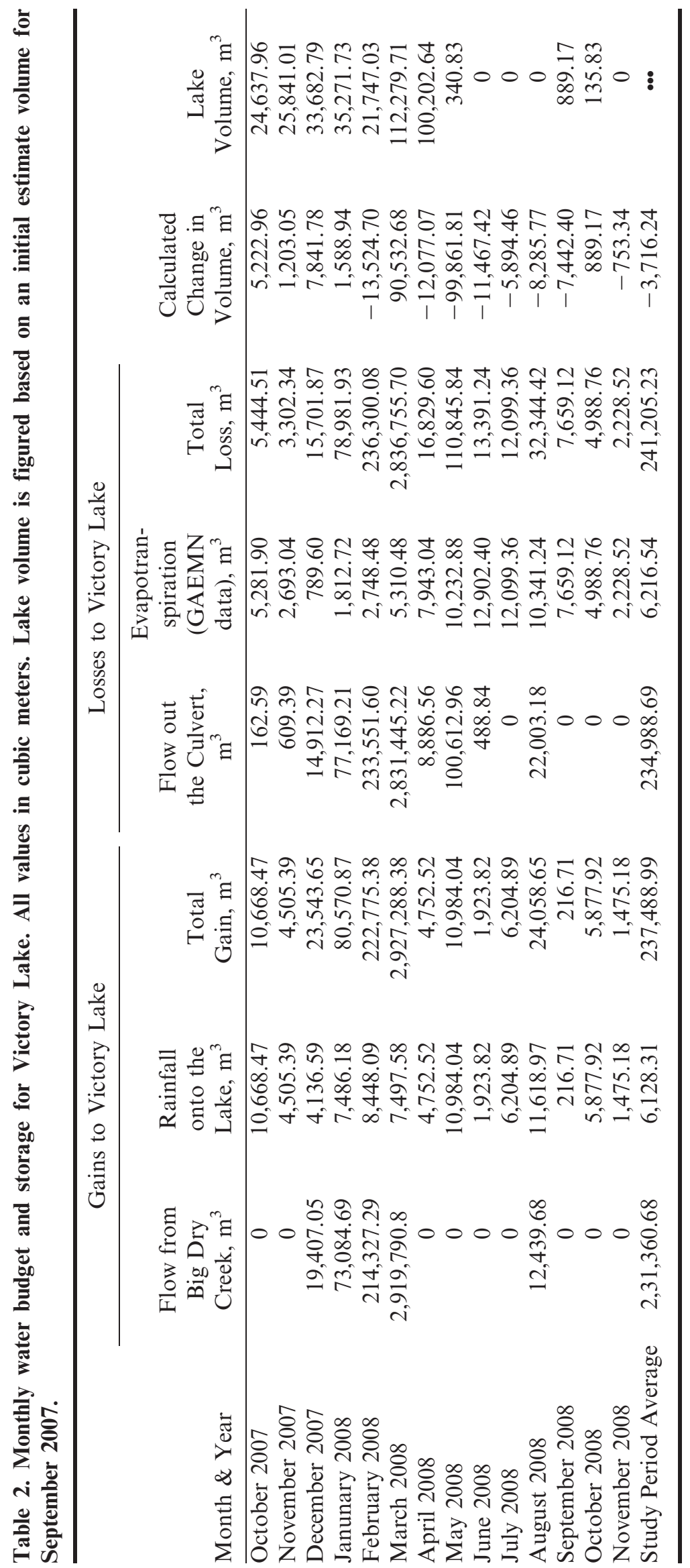


and ${ }^{2} \mathrm{H}$ signatures should be similar. Conversely, if the groundwater and surface water are not connected, the results will be distinctly different. The data shown in Figure 5 indicate that the surface water samples are heavier in ${ }^{18} \mathrm{O}$ and ${ }^{2} \mathrm{H}$. This occurs when the surface water samples have undergone evaporation processes that selectively remove the lighter isotopes $\left({ }^{16} \mathrm{O}\right.$ and $\left.{ }^{1} \mathrm{H}\right)$, leaving an excess of ${ }^{18} \mathrm{O}$ and ${ }^{2} \mathrm{H}$. The groundwater samples show the opposite signature. The distinct difference in the environmental isotope signatures of groundwater and surface water samples indicate that during our study it is likely that the systems were not connected. In addition, from monitoring wells at the southern end of the lake, we measured changes in the water table weekly. Throughout the study the groundwater table was more than $9 \mathrm{~m}$ below the surface. With this evidence we chose to eliminate groundwater inflow from our water budget.

Lake-water seepage into the ground is a challenging parameter to measure. In this study we conducted a Rhodamine WT fluorescent dye-tracer test to check for seepage from surface water to groundwater through a slug injection at the northern end of Victory Lake. During our sampling interval we did not measure any Rhodamine WT in groundwater samples. Next, we considered the very distinct environmental isotope results we retrieved for the groundwater and surface water samples. Moreover, we considered that, prior to human-induced sinkhole formation at the southern end of Victory Lake, the lake basin, which is floored with clay, held water for nearly sixty years. For the purposes of this water budget we eliminated groundwater outflow as a parameter during the duration of the study. Future studies will include geophysical investigation to confirm groundwater flow paths.

The inflow variables measured in this study include inflow from Big Dry Creek draining into Victory Lake and rainfall onto it. This study determined that the stream is ephemeral and only flows after intense rainfall events ( $>35 \mathrm{~mm}$ ) or prolonged rainfall (12 hours or greater). The drainage basin of the primary stream is $5 \mathrm{~km}^{2}$. The area adjacent to the stream just upstream of the lake is a cypress wetland that is usually saturated when we record considerable inflow entering Victory Lake. For the overall water budget of Victory Lake inflow makes up 48\% (Fig. 3). However, when looking at monthly percentages rainfall dominated over stream inflow for most months. This discrepancy is explained by looking at the amount of water entering the system. When substantial precipitation events occur, then surface runoff will contribute to the inflow volume of the stream. The stream does not flow at other times. Therefore, the effects of major precipitation events are multiplied by the surface water runoff into by the stream. These jumps in stream inflow volume were seen in December 2007 through March 2008 (Table 2). Moreover, when precipitation events are lesser in duration and intensity, as from April 2008 to July 2008, the stream does not flow.
During the winter and early spring months the outflow leaving through the culvert was the dominant process occurring $>95 \%$ of the time (Fig. 7). As would be expected, the other outflow component, evapotranspiration, became more prominent during spring and summer months (Fig. 7). Since Victory Lake emptied in 1986, the lake basin has not been full for prolonged periods of time. As a result, fast-growing plants and sedimentation have encroached on the basin to infill most portions. This is why we consider evaportranspiration in this study. More influential by volume of total loss than evapotranspiration was the amount of water lost through the culvert at the southern end of the lake basin ( $49 \%$ overall).

\section{Conclusions}

Nature or human-induced hydrologic changes can alter the fundamental character of karst sites. Worldwide, sinkholes have been an increasing problem. For example, a $60 \mathrm{~km}$ stretch of land along the Dead Sea coast has seen an increase in new sinkhole formation at the rate of 150 to 200 per year, causing drastic alterations to nearby lakes and groundwater flow paths (Yechieli et al., 2006). Similar challenges have been documented in eastern England and western Greece (Cooper et al., 2013; Deligianni et al., 2013). As seen most recently with the emptying of the lakes at Five Blues Lake National Park, Belize, natural or human-induced hydrologic changes can alter the fundamental character of karst sites (Day and Reynolds, 2012). Similar to Five Blue Lake National Park, Floridian lakes Jackson and Scott have also experienced draining due to sinkhole activity (Penson, 2002; McBride et al., 2011). Various water budgets calculated by USGS investigators in karstic areas, like Florida, have helped researchers to better understand water movement and seasonal variability (Dalton et al., 2004; Spechler, 2010; McBride et al., 2011; Sepúlveda et al., 2012). This case study presents a water budget that combines the approaches used by Dalton et al., Spechler, and McBride et al., but was applied to capture a signature of the Rome Formation limestone aquifer in the Ridge and Valley Province of northwest Georgia.

Victory Lake was once a popular, picturesque meeting place and a focal point for visitors and recreation. Sinkhole collapse at Victory Lake twenty-seven years ago resulted in drastic change to campus aesthetics. The restoration of the lake to its original state is of interest to the faculty, students, and staff. From the data collected and analyzed for this study we believe that restoration of Victory Lake is possible. Since the quarrying operations concluded in 2000 there has not been significant sinkhole formation occurring on campus, and the water table has rebounded. Through the development of this water budget we were able to confirm that the groundwater table has stabilized and that the current basin could hold water well enough to support a lake. There are two main reasons that the overall water budget for the lake showed a loss. Over the past 
twenty-seven years the lake has not been maintained or dredged. Ephemeral inflow from Big Dry Creek has caused sedimentation to occur within the basin, causing it to shallow from $2.5-\mathrm{m}$ deep to less than $1 \mathrm{~m}$. The shallow basin morphology encourages surface water to run off quickly. As seen in Figures 2c and 2d, during the growing seasons of spring and summer evapotranspiration due to plant encroachment into the lake drastically reduces the amount of water left in the basin. However, the author admits that only long-term monitoring and continual data collection would confirm that the lake perennially loses more water than it gains, as this research provides limited data for only one hydrologic year.

The challenge in dealing with situations involving the rapid emptying of karst lakes, as suggested by Day and Reynolds (2012), is that sudden underground drainage is a rare phenomenon. The evidence for success of management and restoration of such landscapes to their original form is inconclusive. Although several creative engineering strategies, such as a clay or synthetic liner and a supplemental water supply, have been suggested to rebuild Victory Lake, it remains difficult to weigh the financial investment against the limited guarantee suggested by karst topography. Moreover, the repercussions of the lake emptying for a second time could be the destabilization of downgradient cover-collapse or cover-subsidence sinkholes on campus. This long-term risk to the human health, building infrastructure, and economic loss should be weighed.

Day and Reynolds (2012) suggest that appropriate management strategies in karst terrains should acknowledge the temporal variability of the hydrologic regime and prepare visitors for an experience falling within a wide spectrum of hydrologic conditions. Perhaps this management strategy should be considered at Victory Lake. The current landscape at Victory Lake lends itself easily to a pleasing wetland environment that hosts varying wildlife seasonally. In addition, the mystic of visiting a "disappearing lake" may provide a unique and interesting environmental interpretation of living in a dynamic karst landscape.

\section{ACKNOWLEDGEMENTS}

The author would like to thank the sponsors of the Laura Maddox Smith Environmental Science Grant for providing project funding and NSF grant 0620101 for providing resources and support. Gratitude is extended to the Berry College students who helped in collecting data: Melissa Kemm, Roy Srymanske, Joshua Stevenson, and Lauryn Gilmer.

\section{REFERENCES}

Anderson, C., 1993, Index and short description of the geologic terms used by the GSS: Bulletin of the Georgia Speleological Survey, v. 25, p. 4-8.

Aurit, M.D., Peterson, R.O., and Blanford, J.I., 2013, A GIS analysis of the relationship between sinkholes, dry-well complaints and groundwater pumping for frost-freeze protection of winter strawberry production in Florida: PLoS ONE, v. 8, no. 1, p. 163-167. doi:10. 1371/journal.pone.0053832.

Benito, G., Pérez del Campo, P., Gutiérrez-Elorza, M., and Sancho, C., 1995, Natural and human-induced sinkholes in gypsum terrain and associated environmental problems in NE Spain: Environmental Geology, v. 25, no. 3, p. 156-164. doi:10.1007/BF00768545.

Buhlman, K.A., 2001, A biological inventory of eight caves in northwestern Georgia with conservation implications: Journal of Cave and Karst Studies, v. 63, no. 3, p. 91-98.

Chescheir, G.M., Amatya, D.M., and Skaggs, R.W., 1995, Monitoring the water balance of a natural wetland, in Cambell, K.L., ed., Versatility of Wetlands in the Agricultural Landscape: St. Joseph, Michigan, American Society of Agricultural Engineers, p. 451-462.

Cooper, A.H., Odling, N.E., Murphy, P.J., Miller, C., Greenwood, C.J., and Brown, D.S., 2013, The role of sulfate-rich springs and groundwater in the formation of sinkholes over gypsum in eastern England, in Land, L., Doctor, D.H., and Stephenson, J.B., eds., Proceedings of the 13th Multidisciplinary Conference on Sinkhole and the Engineering and Environmental Impacts of Karst: Carlsbad, National Cave and Karst Research Institute, Symposium 2, v. 13, p. $141-150$.

Craig, H., 1961, Isotopic variations in meteoric waters: Science, v. 133, p. 1702-1703. doi:10.1126/science.133.3465.1702.

Craig, H., and Gordon, L.I., 1965, Deuterium and oxygen 18 variations in the ocean and marine atmosphere, in Tingiorgi, E., ed., Stable Isotopes in Oceanographic Studies and Paleotemperatures: Pisa, Laboratorio de Geologia Nucleare, p. 9-130.

Dalton, M.S., Aulenbach, B.T., and Torak, L.J., 2004, Ground-Water and Surface-Water Flow and Estimated Water Budget of Lake Seminole, Southwestern Georgia, and Northwestern Florida: U.S. Geological Survey, Scientific Investigations Report 2004-5073, 49 p.

Day, M., and Reynolds, B., 2012, Five Blues Lake National Park, Belize: A cautionary management tale: Journal of Cave and Karst Studies, v. 74 , no. 2, p. 213-220. doi:10.4311/2011JCKS0203.

Deevey, S.E., Jr., 1988, Estimation of downward leakage from Florida lakes: Limnology and Oceanography, v. 33, no. 6, p. 1308-1320.

Deligianni, M.G., Veni, G., and Pavlopoulos, K., 2013, Land use and limitations in the sinkhole and polje karst of the Ksiromero Region, Western Greece: Carbonates and Evaporites, v. 28, no. 1-2, p. 167173. doi:10.1007/s13146-013-0133-x.

Fidelibus, M.D., Gutiérrez, F., and Spilotro, G., 2011, Human-induced hydrogeological changes and sinkholes in the coastal gypsum karst of Lesina Marina area (Foggia Province, Italy): Engineering Geology, v. 118 , no. $1-2$, p. 1-19. doi:10.1016/j.enggeo.2010.12.003.

Florea, L.J., Budd, D., and Brinkmann, R., 2009, Caves and karst of West-Central Florida, in Palmer, A.N., and Palmer, M.V., eds., Caves and Karst of the USA; Huntsville, National Speleological Society, p. 189-196.

Hamilton-Smith, E., 2006, Spatial planning and protection measure for karst areas: Acta Carsologica, v. 35, no. 2, p. 5-11.

Healy, R.W., Winter, T.C., LaBaugh, J.W., and Franke, O.L., 2007, Water Budgets: Foundations for Effective Water-Resources and Environmental Management: US Geological Survey, Circular 1308, $90 \mathrm{p}$.

Hebbert, R.H.B., and Smith, R.E., 1990, Hillslope parameter estimation using the inverse procedure: Journal of Hydrology, v. 119, p. 307-334. doi:10.1016/0022-1694(90)90049-4.

Horvat, B., and Rubinic, J., 2006, Annual runoff estimation-an example of karstic aquifers in the transboundary region of Croatia and Slovenia: Hydrological Sciences Journal, v. 51, no. 2, p. 314-324. doi:10.1623/hysj.51.2.314.

Hubbard, D.A., Jr., 1988, Selected Karst Features of the Central Valley and Ridge Province: Virginia Division of Mineral Resources, Publication 83, 1:250,000 scale map with text.

Jenkins, M., 2009, Deep southern caves: National Geographic Magazine, June, 2009, p. 124-141.

Krabbenhoft, D.P., Anderson, M.P., and Bowser, C.J., 1990a, Estimating groundwater exchange with lakes: 2 . Calibration of a three-dimensional, colute transport model to a stable isotope plume: Water Resources Research, v. 26, p. 2455-2462. doi:10.1029/WR026i010p02455.

Krabbenhoft, D.P., Bowser, C.J., Anderson, M.P., and Valley, J.W., 1990b, Estimating groundwater exchange with lakes: 1. The stable isotope mass balance method: Water Resources Research, v. 26, p. 2445-2453. doi:10.1029/WR026i010p02445. 
Krabbenhoft, D.P., Bowser, C.J., Kendall, C., and Gat, J.R., 1994, Use of oxygen-18 and deuterium to assess the hydrology of groundwater/lake systems, in Baker, L.A., ed., Environmental Chemistry of Lakes and Reservoirs: Washington, D.C., American Chemical Society, p. 67-90. doi:10.1021/ba-1994-0237.ch003.

Lindsey, B.D., Katz, B.G., Berndt, M.P., Ardis, A.F., and Skach, K.A., 2010, Relations between sinkhole density and anthropogenic contaminants in selected carbonate aquifers in the eastern United States: Environmental Earth Sciences, v. 60, no. 5, p. 1073-1090. doi:10.1007/ s12665-009-0252-9.

Loague, K.M., and Freeze, R.A., 1985, A comparison of rainfall-runoff modeling techniques on small upland catchments: Water Resources Research, v. 21, no. 2, p. 229-248. doi:10.1029/WR021i002p00229.

MacIntyre, D.F., 1986, A quantitative review of the hydrology of Lake Jackson, Florida, 1971-81, [Masters Thesis]: Gainesville, University of Florida, $238 \mathrm{p}$

Martinez, J.D., Johnson, K.S., and Neal, J.T., 1998, Sinkholes in evaporite rock: American Scientist, v. 86, no. 1, p. 38-51. doi:10.1511/ 1998.1.38.

McBride, W.S., Bellino, J.C., and Swancar, A., 2011, Hydrology, Water Budget, and Water Chemistry of Lake Panasoffkee, West-Central Florida: U.S. Geological Survey Scientific Investigations Report 2010-5237, 96 p.

McCarthy, E.J., Skaggs, R.W., and Farnum, P., 1991, Experimental determination of the hydrologic components of a drained forest watershed: Transactions of the ASABE, v. 34, no. 5, p. 2031-2039.

Newton, J.G., 1987, Development of sinkholes resulting from man's activities in the Eastern United States: U.S. Geological Survey, Circular 968, 54 p.

Penson, G., 2002, Restoring a disappearing lake: Land and Water, v. 46, no. 5 , p. $1-10$

Praise, M., and Gunn, J., 2007, Natural and Anthropogenic Hazards in Karst Areas: Recognition, Analysis and Mitigation: London, Geological Society Special Publications 279, 202 p.

Rosenberry, D.O., Sturrock, A.M., and Winter, T.C., 1993, Evaluation of the energy budget method of determining evaporation at Williams Lake, Minnesota, using alternative instrumentation and study approaches: Water Resources Research, v. 29, no. 8, p. 2473-2483. doi:10.1029/93WR00743.

Scheidt, J., Lerche, I., and Paleologos, E., 2005, Environmental and economic risks from sinkholes in west-central Florida: Environmental Geosciences, v. 12, p. 207-217. doi:10.1306/eg.05130404009.

Schuster, P.F., Reddy, M.M., LaBaugh, J.W., Parkhurst, R.S., Rosenberry, D.O., Winter, T.C., Antweiler, R.C., and Dean, W.E., 2003,
Characterization of lake water and ground water movement in the littoral zone of Williams Lake, a closed-basin lake in north central Minnesota: Hydrologic Processes, v. 17, no. 4, p. 823-838. doi:10. 1002/hyp.1211.

Sepúlveda, N., Tiedeman, C.R., O'Reilly, A.M., Davis, J.B., and Burger, P., 2012, GroundwaterFlow and Water Budget in the Surficial and Floridan Aquifer Systems in East-Central Florida: U.S. Geological Survey Scientific Investigations Report 2012-5161, 214 p.

Spechler, R.M., 2010, Hydrogeology and Groundwater Quality of Highlands County, Florida: U.S. Geological Survey Scientific Investigations Report 2010-5097, 84 p.

Weary, D.J., 2005, An Appalachian regional karst map and progress towards a New National Karst Map, in Kuniansky, E.L., ed., U.S. Geological Survey Karst Interest Group Proceedings, Rapid City, South Dakota, September 12-15, 2005: U.S. Geological Survey Scientific Investigations Report 2005-5160, p. 93-102.

Winstanley, D., Angel, J.A., Changnon, S.A., Knapp, H.V., Kunkel, K.E., Palecki, M.A., Scott, R.W., and Wehrmann, H.A., 2006, The Water Cycle and Water Budgets in Illinois: A Framework for Drought and Water-Supply Planning: Champaign, Illinois, Illinois State Water Survey I/EM 2006-02, 114 p.

Winstanley, D., and Wendland, W.M., 2007, Climate change and associated changes to the water budget, in Dando, W.A., ed., Climate Change and Variations: A Primer for Teachers, v. 1, National Council for Geographic Education, Pathways in Geography 35.

Winter, T.C., 1981, Uncertainties in estimating the water balance of lakes: Journal of American Water Resources Association, v. 17, no. 1, p. $82-115$.

Winter, T.C., 1985, Approaches to the study of lake hydrology, in Likens, G.E., ed., Ecosystem Approach to Aquatic Ecology: Mirror Lake and its Environment, p. 128-135.

Winter, T.C., 1999, Relation of streams, lakes, and wetlands to groundwater flow systems: Hydrogeology Journal, v. 7, p. 28-45. doi:10.1007/s100400050178.

Yechieli, Y., Abelson, M., Bein, A., Crouvi, O., and Shtivelman, V., 2006, Sinkhole "swarms" along the Dead Sea coast: Reflection of disturbance of lake and adjacent groundwater systems: Geological Society of America Bulletin, v. 118, no. 9-10, p. 1075-1087. doi:10. 1130/B25880.1.

Yehdeghoa, B., Rozanski, K., Zojer, H., and Stichler, W., 1997, Interaction of dredging lakes with the adjacent groundwater field: an isotope study: Journal of Hydrology, v. 192, p. 247-270. doi:10.1016/S0022-1694(96)03102-2. 